\title{
PERANCANGAN SISTEM SANITASI LINGKUNGAN DI POSKO BENCANA SINABUNG KONCO KECAMATAN TIGAN DERKET
}

\author{
Arif I'tisham, Ahmad Perwira Mulia dan Hafizhul Khair \\ Jurusan Teknik Lingkungan, Fakultas Teknik, Universitas Sumatera Utara (USU) \\ Jl. Alumni Universitas Sumatera Utara ,Medan 20155 Indonesia \\ e-mail: arifitisham@gmail.com
}

\begin{abstract}
Abstrak-Bencana adalah peristiwa atau rangkaian peristiwa yang mengancam dan mengganggu kehidupan dan penghidupan masyarakat. Jika terjadi bencana, maka akan memunculkan permasalahan yang dapat dikategorikan menjadi 2 (dua), yakni (1) di saat bencana biasanya timbul korban dalam keadaan meninggal atau cedera yang membutuhkan pertolongan medis darurat dan (2) terjadi pengungsian yang memunculkan masalah kesehatan masyarakat pengungsi. Bencana erupsi gunung Sinabung yang terjadi di kota Medan Sumatera Utara merupakan bencana yang dapat menimbulkan permasalahan yang dikategorikan seperti di atas. Sanitasi dan penyediaan air bersih merupakan pokok persoalan yang harus cepat tanggap untuk diselesaikan. Adapun ruang lingkup sanitasi adalah sebagai berikut : Air limbah domestic (Black water \& Grey water), pengelolaan persampahan, drainase lingkungan/tersier. Posko bencana yang terletak didaerah Desa Jandi Meriah kecamatan Tiganderket kabupaten karo menjadi perhatian pada kasus ini. Dengan adanya perencanaan ini diharapkan dapat meminimalisir terjadinya pencemaran lingkungan dan meningkatkan kondisi sanitasi sehingga tingkat kesehatan masyarakat dapat meningkat.
\end{abstract}

Kata Kunci - Bencana, Air Limbah Domestik, Black water, Grey water, Sanitasi, Sistem Pengolahan \& Penyaluran Air Limbah, Pengelolaan Sampah .

\section{PENDAHULUAN}

Bencana erupsi gunung Sinabung yang terjadi di kota Medan Sumatera Utara merupakan bencana yang dapat mengakibatkan korban dan penderitaan manusia,kerugian harta benda,sarana dan prasarana umum serta menimbulkan gangguan terhadap tata kehidupan dan penghidupan masyarakat sehingga memerlukan pertolongan dan bantuan. Sanitasi dan penyediaan air bersih merupakan pokok persoalan yang dibahas pada perancangan ini. Posko bencana Konco yang terletak didaerah Desa Jandi Meriah Kecamatan Tiganderket kabupaten Karo menjadi perhatian pada kasus ini.

Timbulnya masalah pada lingkungan akan menyebabkan penurunan kualitas lingkungan dan tingkat kesehatan masyarakat yang tinggal di Posko bencana Konco, sehingga diperlukan suatu penanganan air limbah , penyediaan air bersih dan pengelolaan sampah yang baik dan terpadu baik dalam penyaluran maupun pengolahannya untuk mengurangi semaksimal mungkin terjadinya pencemaran lingkungan. Melihat pentingnya suatu sistem penyaluran dan pengolahan air limbah,penyediaan air bersih dan pengelolaan sampah, sehingga diperlukan suatu kajian secara teknis berkaitan dengan perancangan sistem sanitasi lingkungan di posko bencana Konco di Kecamatan Tiganderket Kabupaten karo.

Wilayah studi pada perencangan ini berada posko bencana Konco di Kecamatan Tiganderket Kabupaten karo ,Sumatera Utara. Adapun kondisi Eksisting posko bencana Sinabung Konco dapat dilihat pada gambar 1.1 .

Perencanaan sanitasi ini hanya mencakup penyediaan air bersih, penyaluran dan pengolahan air limbah dan pengelolaan sampah . Aspek yang ditinjau yaitu aspek teknis dengan menggunakan beberapa data primer seperti hasil pengamatan kondisi posko bencana dan hasil wawancara. Serta data sekunder tentang kondisi gunung sinabung yang diambil dari BMKG Kaban Jahe. 


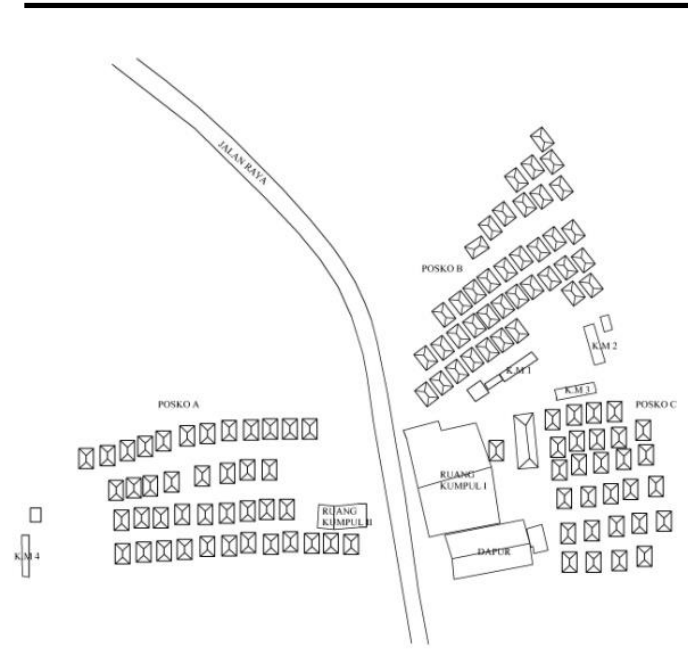

\section{Gambar 1.1 Kondisi Eksisting Posko Bencana Sinabung Konco}

\section{II.METODE PERENCANAAN}

Tahap perencanaan merupakan penjelasan mengenai tahap perencanaan yang telah disusun pada kerangka perencanaan. Tahap perencanaan meliputi judul perencanaan,studi pustaka, pengumpulan data, hasil pembahasan kesimpulan dan saran. Gambar 2.1 menunjukkan tahapan perencanaan :

\section{III.HASIL DAN PEMBAHASAN}

\section{A. Perhitungan Penyediaan Air Bersih}

Perencanan ini menggunakan data data sebagai berikut; penduduk sebesar 936 jiwa dan terdapat 2 sumber air bersih yaitu sumur dan mata air yang digambarkan di gambar 3.1 serta perencanaan ini menggunakan kriteria desain perencanaan SNI 19-6728.1-2002 dengan asumsi keb air bersih daerah pedesaan per jiwa adalah sebesar 100 l/o/hari. Adapun perhitungan kebutuhan air bersih pada posko bencana dengan studi kasus posko bencana Konco sinabung ;

Keb air bersih $=100$ 1/org/hari x 936 jiwa

$$
\begin{aligned}
& =936001 / \text { hari } \\
& =93,6 \mathrm{~m}^{3} / \text { hari }
\end{aligned}
$$

Jumlah pemakaian air perjam kerja ;

$$
Q h=\frac{Q d}{\mathrm{t}}
$$

Ket:

Qd : Kebutuhan rata rata air bersih $\mathrm{t} \quad$ : waktu pemakaian air per jam kerja (asumsi)

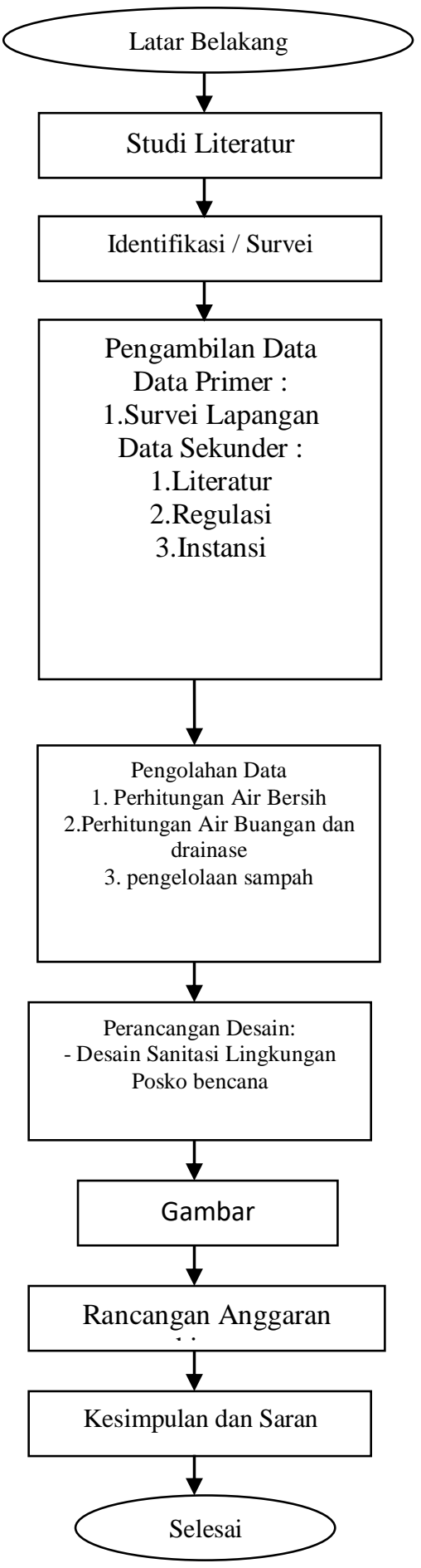




$$
\begin{aligned}
\mathrm{Qh} & =\frac{93,6 \mathrm{~m} 3 / \text { hari }}{8} \\
& =11,7 \mathrm{~m}^{3} / \mathrm{jam}
\end{aligned}
$$

Jumlah pemakaian air perjam puncak:

Ket:

$$
\mathrm{Qh}-\max =\mathrm{C} 1 \mathrm{x} \text { Qh }
$$

Qh-max : Pemakaian air perjam puncak

C1 : Konstanta pemakaian air bekisar antara 2,0 - 4,0

Qh-max $=2 \times 11,7 \mathrm{~m}^{3} / \mathrm{jam}$

$=23,4 \mathrm{~m}^{3} / \mathrm{jam}$

Desain Kapasitas pipa ;

Diasumsi kan pemakaian air dari sumber 1 pada posko bencana Konco ini dalam 1 hari (24 jam) adalah $100 \%$.

Maka \% kebutuhan air yang harus dipenuhi oleh pompa tiap hari pada sumber 1 adalah :

$$
1 / 24 \times 100 \%=4,17 \%
$$

Pemakaian pompa per hari dari sumber mata air 2 untuk mengisi penuh reservoir atau tangki adalah 8 jam. Maka \% kebutuhan air yang harus dipenuhi oleh pompa tiap hari pada sumber 2 adalah :

$$
1 / 8 \times 100 \%=12,50 \%
$$

Maka, besar kapasitas pipa dapat dihitung sebagai berikut :

$$
\begin{aligned}
\mathrm{Q}_{\mathrm{s}} & =(12,50-4,17) \% \times \mathrm{Qh} \\
& =0,0833 \times 11,7=0,97 \mathrm{~m}^{3} / \mathrm{jam}
\end{aligned}
$$

Besar volume tampung ;

$$
\begin{aligned}
\text { Qs } \mathrm{x} \mathrm{t} & =0,97 \times 8 \\
& =7,8 \approx 8 \mathrm{~m}^{3}=80001
\end{aligned}
$$

Dengan volume air yang dibutuhkankan sebesar 80001 , direncanakan memakai jenis jenis tangki yang beredar di pasaran dengan volume tangki yang di butuh kan 20001 (asumsi) jadi didapat kebutuhan tangki sebesar :

$$
80001: 20001=4 \text { tangki }
$$

Jadi kebutuhan air bersih pada posko bencana Konco sebesar 8000 l dengan di wadahi tangki 20001 sebanyak 4 buah tangki. Layout sistem penyediaan air bersih dapat di lihat pada gambar 3.1 ;

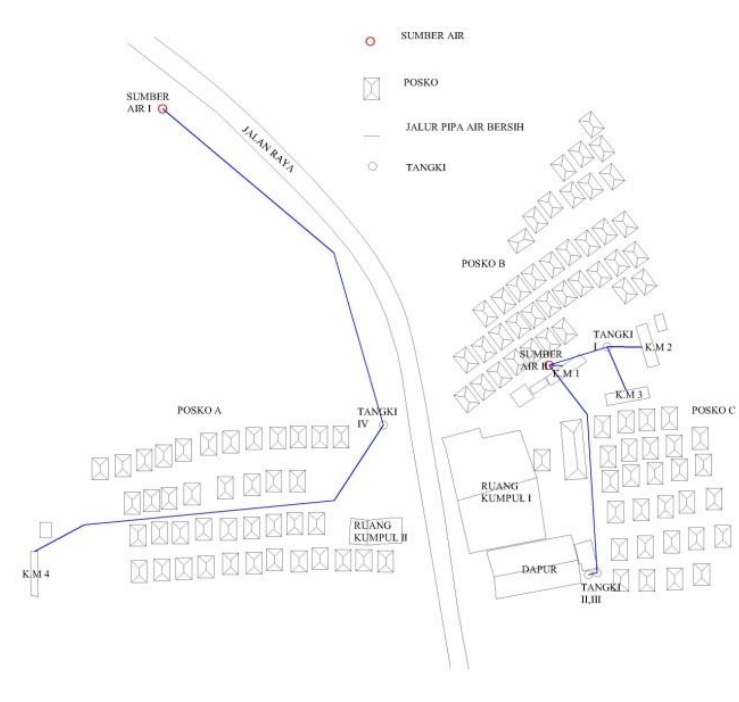

\section{Gambar 3.1 Layout Perencanaan Sistem Penyediaan Air bersih}

\section{B. Perhitungan Pengolahan air buangan \\ B.1 Tangki Septik}

Dalam perancangan ini pengolahan air buangan yang direncanakan menggunakan tangki septik. Tanki septik yang akan dibangun terdiri daridua buah ruang. Ruang pertama merupakan ruangpengendapan lumpur. Volume ruang pertama ini memiliki volume $40-70 \%$ dari keseluruhan volume tangki septik. Pada ruang kedua merupakan ruang pengendapan bagi padatan yang tidak terendapkan pada ruang pertama. Panjang ruangan pertama dari tangki septik sebaiknya dua kali panjang ruangan kedua, dan panjang ruangan kedua sebaiknya tidak kurang dari 1 $\mathrm{m}$ dan dalamnya $1,5 \mathrm{~m}$ atau lebih, dapat memperbaiki kinerja tangki. Kedalaman tangki sebaiknya berkisar antara 1,0-1,5 m. Sedangkan celah udara antara permukaan air dengan tutup tangki (free board) sebaiknya antara 0,3 hingga $0,5 \mathrm{~m}$. Tangki septik harus dilengkapi dengan lubang ventilasi (dipakai pipa tee) untuk pelepasan gas yang terbentuk dan lubang pemeriksaan yang digunakan untuk pemeriksaan kedalaman lumpur serta pengurasan.(Sapei dkk ,2011)

Perhitungan estimasi pekiraan kapasitas tangki septik yang akan digunakan untuk melayani 265 kk pada posko bencana Konco, diasumsikan bahwa :

a. Total jumlah penduduk terlayani ; 936 orang.

b. Waktu asumsi pengurusan direncanakan setiap

(N) 2 tahun (IKK Sanitation Improvement 
I'thisam, A. et al. Perancangan Sistem Sanitasi Lingkungan di Posko Sinabung ...

Programme, 1987, dalam NMC CSRRO DI Yogyakarta)

c. Rata-rata lumpur terkumpul liter/orang/tahun adalah 40 liter untuk air limbah dari WC.

d. Air limbah yang dihasilkan tiap orang/hari adalah10 liter/orang/hari (tanki septic hanya untuk menampung limbah WC).

Estimasi perhitungan dari asumsi di atas adalah

sebagai berikut:

Kebutuhan kapasitas penampung untuk lumpur

(A), adalah:

$$
\mathrm{A}=\mathrm{P} \cdot \mathrm{N} . \mathrm{S}
$$

Dengan:

$\mathrm{A}=$ Penampungan lumpur yang diperlukan (dalam liter)

$\mathrm{P}=$ Jumlah orang yang diperkirakan menggunakan tangki septik

$\mathrm{N}=$ Jumlah tahun jangka waktu pengurasan lumpur

$\mathrm{S}=$ Rata-rata lumpur terkumpul (liter/orang/tahun).

Sehingga,

$\mathrm{A}=936$ orang $\mathrm{x} \quad 2$ tahun $\mathrm{x} \quad 40$

liter/orang/tahun

$=74880$ liter $=74,8 \mathrm{~m} 3$

Keperluan waktu penahan minimum dalam satu

hari (Th), adalah:

$$
\mathrm{T}_{\mathrm{h}}=2,5-0,3 \log (\mathrm{P} . \mathrm{Q})>0,5
$$

Dengan:

Th = Keperluan waktu penahanan minimum untuk pengendapan $>0,51 /$ hari

$\mathrm{P}=$ Jumlah orang

$\mathrm{Q}=$ Banyaknya aliran, liter/orang/hari

Sehingga,

$$
\begin{aligned}
& \text { Th = 2,5-0,3log (936 org X } 10 \\
& \text { liter/org/hari) }>0,5 \\
& =1,3>0,5 \text { 1/hari }
\end{aligned}
$$

Kebutuhan kapasitas penampung air (B), adalah:

Sehingga,

$$
\mathrm{B}=\mathrm{P} . \mathrm{Q} . \mathrm{Th}
$$

$\mathrm{B}=936$ orang .10 liter/orang/hari . 1,3 liter/hari$$
=12168 \text { liter }=12,168 \mathrm{~m}^{3}
$$

Volume tangki septik komunal

$=\mathrm{A}+\mathrm{B}$

$=(74,8+12,168) \mathrm{m}^{3}$

$=28,989 \mathrm{~m}^{3}$

Dimensi tangki septik komunal adalah:
Tinggi tangki septik $(h)=1,5 \mathrm{~m}+0,3 \mathrm{~m}$ (free board /tinggi jagaan).

Perbandingan lebar tangki septik (L): panjang tangki septik $(\mathrm{P})=1: 2$

Lebar tangki septik $=2,62 \mathrm{~m}$

Panjang tangki septik $=5,242 \mathrm{~m}$

Adapun desain teknis Tangki Septik dapat dilihat pada gambar 3.2 dan 3.3 ;

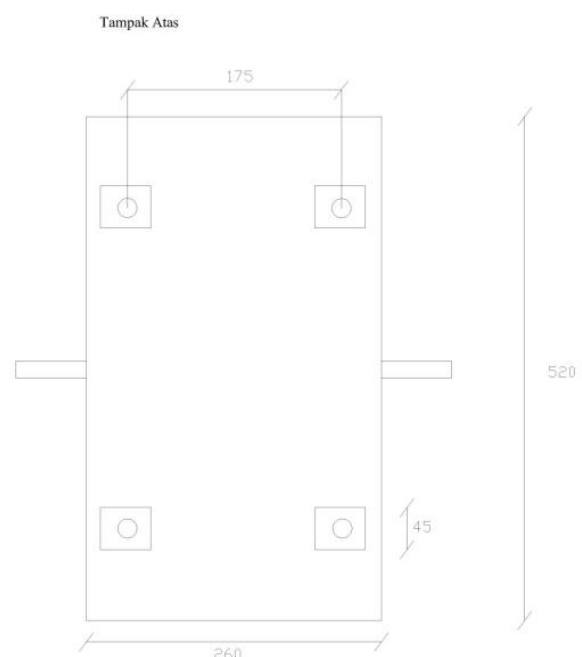

\section{Gambar 3.2 Desain Teknis Tangki Septik tampak atas}

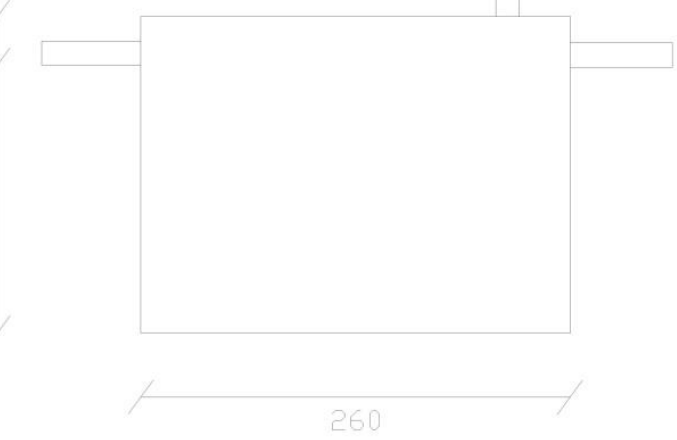

Tampak Depan

\section{Gambar 3.3 Desain Teknis Tangki Septik tampak depan}

\section{B.2 Sumur Resapan}

Peresapan berfungsi untuk meresapkan cairan yang keluar dari tangki septik ke tanah secara horisontal dan vertikal melalui pori pori tanah. Material organik akan diolah oleh bakteri yang hidup dalam tanah. Perubahan temperatur dan karakteristik kimiawi serta persaingan makanan dengan bakteri tanah juga akan bisa mengakibatkan bakteri dan virus yang ada dalam cairan yang keluar dari 
I'thisam, A. et al. Perancangan Sistem Sanitasi Lingkungan di Posko Sinabung ...

tangki septik terbunuh. Air limbah umumnya akan meresap kedalam tanah dan akhirnya masuk ke dalam air tanah sedangkan sebagian akan bergerak keatas akibat gaya kapiler selanjutnya menguap serta diserap tanaman. Peresapan disini berfungsi sebagai pengolahan sekunder dan pembuangan akhir. (Sapei dkk ,2011)

Jenis peresapan yang bisa digunakan sebagai berikut (Sapei dkk, 2011):

a. Bidang resapan. Jenis peresapan ini dibuat dengan bentuk seperti parit (arah horisontal atau memanjang) sehingga kelemahannya adalah memerlukan banyak tempat, namun jenis tersebut efektifitasnya lebih tinggi dibanding sumur resapan.

b. Sumur peresapan. Jenis peresapan ini dibuat dengan bentuk sumur (arah vertikal), dengan dinding yang bisa meresapkan air (dinding berlubang) dengan dasar tanah (tanpa perkerasan). Jenis ini digunakan jika ketersediaan tanah tidak memungkinkan dibuat bidang resapan dan kedalaman muka air tanah tertinggi (saat musim hujan) minimal 1,5 m dari dasar sumur resapan.

Secara umum konstruksi sumur resapan lebih sederhana dibanding dengan bidang resapan. Sumur Resapan bisa dibiarkan kosong dan dilapisi dengan bahan yang bisa menyerap (untuk penopang dan mencegah longsor), atau tidak dilapisi dan diisi dengan batu dan kerikil kasar. Batu dan kerikil akan menopang dinding agar tidak runtuh, tapi masih memberikan ruang yang mencukupi untuk air limbah. Dalam kedua kasus ini, lapisan pasir dan kerikil halus harus disebarkan diseluruh bagian dasar untuk membantu penyebaran aliran. Kedalaman sumur resapan harus 1,5 dan 4 meter, tidak boleh kurang dari 1,5 meter diatas tinggi permukaan air tanah, dengan diameter $1,0-$ 3,5 meter. Sumur ini harus diletakkan lebih rendah dan paling tidak 15 meter dari sumber air minum dan sumur. Sumur resapan harus cukup besar untuk menghindari banjir dan luapan air. Kapasitas minimum sumur resapan harus mampu menampung semua air limbah yang dihasilkan dari satu kegiatan mencuci atau dalam satu hari, volume manapun yang paling besar. Perencanaan Sumur Resapan dapat dilihat pada gambar 3.4

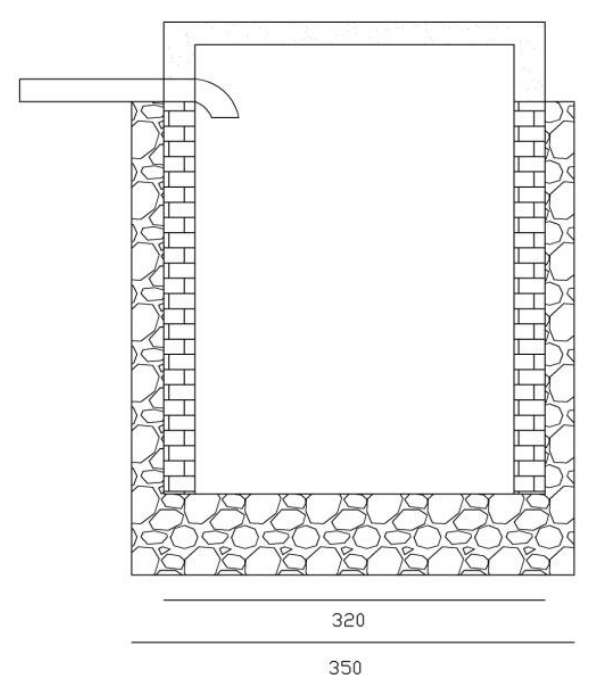

Gambar 3.4 Desain Teknis Sumur Resapan

C. Perhitungan Pengelolaan sampah C.1 Umum

Perencanaan ini membutuhkan data sebagai berikut ; jumlah penduduk yang dilayani : 936 jiwa dan memakai kriteria desain diambil dari Permen PU no 3 tahun 2013 . Pada perencanan pengelolaan sampah di posko bencana Konco ini direncanakan menggunakan TPST. Adapun penjelasan TPST diambil dari Permen PU no 3 tahun 2013 ;

TPST atau Material Recovery Facility (MRF) didefinisikan sebagai tempat berlangsungnya kegiatan pemisahan dan pengolahan sampah se cara terpusat. Kegiatan pokok di TPST adalah:

1. pengolahan lebih lanjut sampah yang telah dipilah di sumbernya

2. pemisahan \& pengolahan langsung komponen sampah kota

3. peningkatan mutu produk recovery/recycling

Sehingga fungsi TPST adalah sebagai tempat berlangsungny a pemisahan, pencucian / pembersihan, pengemasan, dan pengiriman produk daur ulang sampah.

\section{C.2.Rancangan TPST}

TPST sebagai tempat daur ulang sampah, memerlukan fasilitas berdasarkan komponen sampah yang masuk dan yang akan dikelola. Pada perhitungan timbulan sampah pada posko bencana ini dengan studi kasus posko bencana Konco dipakai kriteria perancangan 
I'thisam, A. et al. Perancangan Sistem Sanitasi Lingkungan di Posko Sinabung ...

menggunakan SNI 3.04-1993.03 yang terdapat pada tabel 3.1 ;

Tabel 3.1 Jumlah timbulan berdasarkan SNI 3.04-1993.03

\begin{tabular}{|l|l|l|l|l|}
\hline No & $\begin{array}{l}\text { Komponen } \\
\text { Sumber } \\
\text { sampah }\end{array}$ & Satuan & Vol (1) & $\begin{array}{l}\text { Berat } \\
(\mathrm{Kg})\end{array}$ \\
\hline 1 & $\begin{array}{l}\text { Rumah } \\
\text { Permanen }\end{array}$ & $1 /$ o/hari & $\begin{array}{l}2,25- \\
2,5\end{array}$ & $\begin{array}{l}0,35- \\
0,4\end{array}$ \\
\hline 2 & $\begin{array}{l}\text { Rumah } \\
\text { semi } \\
\text { permanen }\end{array}$ & $1 /$ o/hari & $2-2,25$ & $0,3-$ \\
& $\begin{array}{l}\text { Rumah non } \\
\text { permanen }\end{array}$ & $1 / 0 / \mathrm{hari}$ & $1,75-2$ & $0,25-$ \\
\hline 3 & & & 0,3 \\
\hline 4 & Jalan lokal & $1 / \mathrm{m}^{2} / \mathrm{hari}$ & $0,2-0,6$ & $0,1-$ \\
& & & & 0,3 \\
\hline
\end{tabular}

Pada perencanaan in di asumsikan tenda sebagai rumah non permanen pada SNI 3.041993.03 maka didapat

936 jiwa 22 1/o/hari = 1872 1/o/hari $=1,9 \mathrm{~m}^{3} /$ hari $\approx 2 \mathrm{~m}^{3} /$ hari

Dari hasil perhitungan maka didapat lah jumlah timbulan sampah posko bencana sebesar $2 \mathrm{~m}^{3} /$ hari . Untuk mengetahui volume TPST yang dibutuhkan dapat menggunakan kriteria perancangan dari Permen PU no 3 tahun 2013 yang dijelaskan pada tabel 3.2 ;

Tabel 3.2 Luas TPS dan Volume Kontainer berdasarkan Permen no 3 tahun 2013

\begin{tabular}{|c|c|c|}
\hline $\begin{array}{c}\text { Luas Lahan } \\
\text { TPS }\left(\mathrm{m}^{2}\right)\end{array}$ & $\begin{array}{c}\text { Dimensi } \\
\text { Lahan }(\mathrm{m} \times \mathrm{m})\end{array}$ & $\begin{array}{c}\text { Volume } \\
\text { Kontainer yang } \\
\text { digunakan }\left(\mathrm{m}^{3)}\right.\end{array}$ \\
\hline 50 & $5 \times 10$ & 8 \\
\hline 100 & $10 \times 10$ & 8 \\
\hline 200 & $10 \times 20$ & 14 \\
\hline 300 & $10 \times 30$ & 14 \\
\hline 400 & $15 \times 27$ & 14 \\
\hline 500 & $15 \times 34$ & \\
\hline
\end{tabular}

\begin{tabular}{|l|c|c|}
\hline 1000 & $15 \times 67$ & 14 \\
\hline
\end{tabular}

Dengan luas lahan yang tersedia di posko bencana Konco $\pm 50 \mathrm{~m}^{2}$ maka didapat kontainer yang dibutuhkan sebesar $8 \mathrm{~m}^{3}$ dengan timbulan sampah $\pm 2 \mathrm{~m}^{3} /$ hari.

\section{IV.KESIMPULAN}

Jurnal Perancangan Sistem Sanitasi Lingkungan di Posko Bencana Sinabung Konco Kecamatan Tigan Derket , memberikan perencanaan desain; a. Penyediaan air bersih dengan kebutuhan air sebesar 80001 menggunakan 4 tangki 20001

b. Pengolahan air buangan dengan tangki septik yang berdimensi Tinggi $(\mathrm{h})=1,8 \mathrm{~m}$, Lebar tangki septik $=2,62 \mathrm{~m}$, Panjang tangki septik $=5,242 \mathrm{~m}$

c. Pengelolaan sampahdengan timbulan sampah perharinya sebesar $2 \mathrm{~m}^{3} /$ hari dengan wadah / TPST menggunakan kontainer berukuran $8 \mathrm{~m}^{3}$

\section{UCAPAN TERIMA KASIH}

Penulis menyampaikan penghargaan dan terima kasih kepada Bapak Dr.Ir.Ahmad Perwira Mulia, M.Sc , Bapak Hafizhul Khair AM ST, MT dan Ibu Isra Suryati ST, M.Si yang telah mendukung dan membimbing penulisan jurnal ini. Terima kasih juga disampaikan kepada Abdul Hafidz Nainggolan dan M.Andhika Tri $\mathrm{H}$ yang telah banyak membantu dalam pembuatan jurnal ini.

\section{DAFTAR PUSTAKA}

Badan Standar Nasional (2002): Tata Cara Perencanaan Bangunan MCK Umum - SNI 03- 2399-2002.

Andriani, Zella . 2016 . Perencanaan Peningkatan Pelayanan Sanitasi di Kelurahan Pegirian Surabaya, Jurusan Teknik Lingkungan, Fakultas Teknik Sipil dan Perencanaan ,ITS ; Surabaya

Arikunto, Suharsimi. 2002. Prosedur Perancangan Suatu Pendekatan Praktek. Jakarta : Rineka Cipta.

Hariwijaya, M. dan Bisri M. Djaelani.2008. Teknik Menulis Skripsi dan Tesis Disertai Contoh Proposal Skripsi. Yogyakarta: Hanggar Kreator. 
I'thisam, A. et al. Perancangan Sistem Sanitasi Lingkungan di Posko Sinabung ...

Mawandy, Erwin. 2003. Studi Problematik Pemanfaatan Ruang dan Manajemen pada Stasiun Kereta Api Gambir. Tugas Akhir. Jurusan Teknik Planologi. Jakarta : Universitas Indonusa Esa Unggul.

Narbuko, Cholid dan Abu Achmadi. 2008 Metodologi Perancangan, Jakarta : Bumi Aksara.

Sapei, Asep dkk , 2011. Desain Instalasi Pengolahan Limbah WC Komunal Masyarakt Pinggir Sungai Desa
Lingkar Kampus . Deartemen teknik sipil dan lingkungan, Fakultas Teknologi Pertanian ;Bogor : IPB

Sugiyono. 2008. Metode Perancangan Bisnis. Bandung : PT Alfabeta.

United Nations. Laporan Pencapaian Milenium Development Indonesia Tahun 2004 